Another major problem is that of control of settlements. If reliance is placed upon the action of the intermediate party, he may settle for an insufficient amount. In the Robins Dry Dock case, the owner settled for an amount which exceeded his own loss, but did not cover that of the charterer. If the third party is foreclosed by such an agreement, the door is open for collusive settlements. On the other hand, if the intermediate party may settle only as to his own claim, and third parties retain an independent claim, settlements will be made more difficult, for defendants will fear that there may be some hidden third party whose claim is not being settled.

A final objection is that a direct third-party cause of action might require the tortfeasor to defend against multiple actions. But in many cases the actions will be joined; moreover, the common situation is where there will be only two plaintiffs, as in the Harrison case. In any event, the third party is innocent; the defendant is not.

Although direct third-party recovery has been found to be desirable in certain cases, the weight of precedent is opposed to it. Most of the cases involving injury to the economic interests of third parties have been disposed of on grounds of remoteness, and discussion has ended there. But further analysis has disclosed that this class of third-party actions is not uniform-that although some recoveries would extend liability, others would not. The distinction proposed would achieve the advantageous result of permitting third-party recovery where this is possible without increasing the amount of damages payable by the tortfeasor. In the absence of a discernible supervening policy, this distinction seems as appropriate to antitrust actions as to others.

\title{
JUDICIAL EXERCISE OF EQUITABLE DISCRETION IN ENFORCEMENT OF ARBITRATION CONTRACTS
}

A quarter of a century of experience with federal and state arbitration statutes has suggested to some observers that arbitration, despite its great usefulness in many situations, does not always achieve better results than could the courts. Many judges, brought into contact with arbitration contracts by virtue of statutory provisions for enforcement and review, have demonstrated their agreement with this evaluation. This attitude is most apparent in their frequent refusal to enforce such contracts at the outset of the arbitration process in cases in which they have felt more equitable results would be achieved through judicial procedures.

Opportunities for judicial influence over the outcome of arbitrable disputes are presented not only in review of arbitrator's decisions but at the several points at which statutes provide for judicial action before arbitration commences. A court may be asked to issue an order directly compelling the parties to arbitrate, to stay judicial proceedings where under the terms of the contract 
the issues are referable to arbitration, or to appoint arbitrators where a party has failed in his contractual obligation to do so. ${ }^{1}$

On many occasions courts have refused these enforcement remedies on equitable grounds in spite of a clear legislative policy favoring settlement by arbitration. Since the statutes appear to give no clear authority for such discretionary refusal this result is achieved only by strained construction of the arbitration clause in question or by free interpretation of the statutory language.

For example, in a recent decision, $R F C$ v. Harrisons \& Crosfield, ${ }^{2}$ the Court of Appeals for the Second Circuit considered laches as a defense in a suit to compel arbitration under the United States Arbitration Act. Although the narrow holding of the case-that laches ran from the time of the refusal to arbitrate rather than from the time of the alleged breach of a substantive term in the contract ${ }^{3}$ -may be of little practical significance, the premise of the decision, that a defense such as laches might be available, raises sharply the issue of whether the arbitration statutes permit courts to exercise equitable discretion in enforcement proceedings. The purpose of this comment will be to consider this question and the broader issue which it in turn suggests-whether, apart from statutory interpretations, courts can best assist in the efficient and just resolution of arbitrable disputes by such use of their equitable powers.

\section{I}

On its face the United States Arbitration Act ${ }^{4}$ gives no clear authority to the courts for the exercise of equitable discretion. ${ }^{5}$ Section 2 makes enforceable cer-

${ }^{1}$ While the arbitration acts differ substantially, all provide essentially the same methods of enforcement with the important exception of the order directly compelling arbitration. The New York Draft Act and those patterned after it (including the federal act) provide for the order while the Uniform and English Arbitration Acts do not. N.Y. Civ. Practice Act $\$ \$ 1448-$ 69 (Thompson, 1939); Uniform Arbitration Act; The Arbitration Acts (Eng.) 52 \& 53 Vict. c. 49 (1889), $24 \& 25 \mathrm{Geo}$. V, c. 14 (1934). For a review of the remedies available under the common law, consult: 6 Williston, Contracts $\S 1927$ A (Williston \& Thompson rev. ed., 1938), or Judge Frank's comprehensive opinion in Kulukundis Shipping Co. v. Amtorg Trading Corp., 126 F. 2d 978 (C.A. 2d, 1942).

204 F. 2 d 366 (C.A. 2d, 1953), cert. denied 346 U.S. 854 (1953).

${ }^{3}$ The breach of a substantive term in the contract, i.e., failure to procure insurance, occurred in 1942. The demand for arbitration was first submitted and refused in 1951. Judge Clark in a dissenting opinion suggested that the view which Judge Frank held would "surely ... make of limitation a "topsy-turvy land." Ibid., at 371. Since a demand is ordinarily required before a court will entertain suit to compel arbitration, the New York statute, which the court found to be controlling, would seem to indicate that failure to make the demand should not prevent the limitation period from running: "Where a right exists, but a demand is necessary to entitle a person to maintain an action, the time within which the action must be commenced must be computed from the time when the right to make the demand is complete...." N.Y. Civ. Practice Act $\$ 15$ (Thompson, 1939). The principal case has been noted in the following law reviews: 39 Cornell L.Q. 107 (1953); 67 Harv.L. Rev. 510 (1954); 38 Minn. L. Rev. 264 (1954).

143 Stat. 883 (1925), repealed and re-enacted into positive law by 61 Stat. 669 (1947), 9 U.S.C.A. $\$ \S 1-14$ (1953).

5 The congressional committee reports reflect no real concern for equity but indicate an intention merely to place arbitration contracts on the same level with other contracts. House 
tain contracts in interstate commerce and maritime transactions "save upon such grounds as exist at law or in equity for the revocation of any contract." Later sections provide appropriate remedies for enforcement but do not advert to equity. Section 3 provides for a stay of court proceedings where the issues in dispute are referable to arbitration under the contract, and Section 4 indicates that on finding the "making of the agreement" and "failure to comply therewith" a court "shall" order the parties to proceed to arbitration. Similar mandatory language appears also in Section 3.

Accepting the mandatory language at face value, the early commentaries and decisions under the Act assumed that no equitable discretion could be exercised, and on this basis the Act was criticized. ${ }^{6}$ As a result, courts in several of the early decisions engaged in strained and technical interpretations of the clauses before them to withhold the disputes from arbitration. In one case ${ }^{7}$ under the New York statute, the clause covered "all questions that may arise under this contract and in the performance of the work thereunder." The court, however, held that a controversy over delays and amounts due was not covered by the clause on the grounds that the dispute involved violation or nonperformance of the contract rather than performance under it. The court further decided that "by filing a mechanics' lien [the parties seeking relief] set out on a course so inconsistent with arbitration that they must be regarded as having decisively elected to waive and abandon their right to that course."8

In the 1930's, however, the federal courts began turning to principles of equity to achieve their results, and highly technical grounds for refusing enforcement were not so often relied upon. In effect the courts simply ignored the mandatory language of the Act and asserted that the order compelling arbitration was an equitable one. From this premise it followed that equitable doctrines

Committee on the Judiciary, Report No. 96 to accompany H.R. 646, 68th Cong. 1st Sess. (1923); Senate Committee on the Judiciary, Report No. 536 to accompany Sen. 1005, 68th Cong. 1st Sess. (1923).

"Is equity history to be taken so lightly and equitable principles to be so disregarded that specific performance, always a remedy in the discretion of the chancellor is now to be granted wholesale, without thought? ... Equity saw good reason why Madame Wagner should not be compelled to sing, but business forgets that when it asks that contracts to arbitrate be specifically enforced, and without the chancellor having discretion to deny the enforcement." Phillips, The Paradox in Arbitration Law, 46 Harv. L. Rev. 1258, 1266 (1933). See also: Phillips, A Lawyer's Approach to Commercial Arbitration, 44 Yale L.J. 31 (1934); Simpson, Specific Enforcement of Arbitration Contracts, 83 U. of Pa. L. Rev. 160 (1934).

7 Young v. Crescent Development Co., 240 N.Y. 244, 140 N.E. 510 (1925).

8 Ibid., at 249 and 511 . The device of narrowing the scope of a seemingly broad arbitration clause to exclude the particular dispute was used elsewhere. Smith Fireproof Const. Co. v. Thompson-Starrett Co., 247 N.Y. 277, 160 N.E. 369 (1928); Marchant v. Mead-Morrison Mfg. Co., 252 N.Y. 284, 169 N.E. 386 (1929). For examples of similar devices, see: Lehigh Structural Steel Co. v. Rust Engineering Co., 59 F. 2d 1038 (App. D.C., 1932); Colwell Worsted Mills v. Glass, 228 App. Div. 150, 239 N.Y. Supp. 281 (1st Dep't, 1930). 
could be used to justify not only a refusal to compel but also the issuance of special orders designed to meet peculiar situations.

For example, in In re Utility Oil Corp. ${ }^{9}$ a federal court refused to enforce an arbitration clause strictly according to its terms but rather applied a "fair and equitable interpretation in line with the dominant intent of the parties." The contract provided that upon the failure of one party to appoint an arbitrator the one chosen by the other party should consider the dispute and render an award. The court ignored this provision and allowed the defendant to appoint an arbitrator since his initial refusal was based on a good-faith contention that the dispute was not covered by the arbitration clause.

Courts also have spoken in terms of equity when dealing with an application for a stay order under the Act. In one case the court refused to grant the order on the legal grounds of waiver and delay, but went on to say that "[t]he trial judge is vested with discretion to refuse to stay the action if he is of the opinion that the party seeking arbitration is in default." ${ }^{10}$ While such a statement is not a bold assertion of equity power, it tends to suggest some degree of judicial discretion to meet the facts of each case.

Proceedings under arbitration statutes have also been designated as "equitable in nature" when the remedy granted would not have been available at law. The New York Court of Appeals held in Matter of Feuer Transportation ${ }^{11}$ that relief not specifically asked for in the complaint might nonetheless issue - in this case, court appointment of arbitrators. The court relied on the principle that "[i]n equity, proper relief is ordinarily granted when the facts warrant regardless of what may have been asked for."12 Too, the federal courts have granted interlocutory orders designed to preserve the status quo pending a decision by the arbitration board. In cases otherwise justiciable in admiralty the Act provides for libel and seizure, ${ }^{13}$ but where the action involves only interstate commerce equity must again be relied upon in granting interlocutory injunctions to preserve the subject matter of the dispute. Thus it has been held that a necessary concomitant of the power to compel arbitration is the right to issue whatever orders are appropriate to protect the rights of each party until a final decision is forthcoming. ${ }^{14}$

910 F. Supp. 678 (S.D. N.Y., 1934).

${ }^{10}$ Radiator Specialty Co. v. Cannon Mills, 97 F. 2d 318, 319 (C.A. 4th, 1938).

11295 N.Y. 87, 65 N.E. 2d 178 (1946). $\quad 12$ Tbid., at 92 and 180.

1361 Stat. 669 (1947), 9 U.S.C.A. $\$ 8$ (1953). Cf. The Anaconda v. American Sugar Refining Co., 322 U.S. 42 (1944).

${ }_{14}$ Murray Oil Products Co. v. Mitsui \& Co., 146 F. 2d 381 (C.A. 2d, 1944); Albatross S.S. Co. v. Manning Bros., 95 F. Supp. 459 (S.D. N.Y., 1951). But cf. Young v. Crescent Development Co., 240 N.Y. 244, 148 N.E. 510 (1925), discussed supra page 721. Guarded assertions of a freedom of discretion have been made in several other cases but the discretion was not necessary to the decision. American Locomotive Co. v. Chemical Research Corp., 171 F. 2d 115 (C.A. 6th, 1948); Almacenes Fernandez S.S. v. Golodetz, 148 F. 2d 625 (C.A. 2d, 1945); Postal S.S. Co. v. International Freighting Corp., 133 F. 2d 10 (C.A. 5th, 1943). 
II

The rather hesitating nature of these forays into the realm of equity suggests that no satisfactory justification had yet been found for the exercise of equitable discretion under the statutes. However, Judge Frank's remarks in the RFC case $^{15}$ and in Kulukundis Shipping Co. v. Amtorg Trading Corp. ${ }^{16}$ indicate at least two possible grounds for invoking equity.

A footnote to the opinion in the $R F C$ case suggests that the court relied upon the language of Section 2- "valid, irrevocable, and enforceable, save upon such grounds as exist at law or in equity for the revocation of any contract"-as the source of a general equity power. ${ }^{17}$ But the court did not explain how Section 2 could be used to overcome the mandatory language of Sections 3 and 4 . And there are two further arguments indicating that equitable discretion is not properly derived from Section 2.

The first argument arises from the ambiguity of the word "revocation." The decisions under the statutes have not discussed the meaning of the term. In common-law arbitration, as Dean Sturges has pointed out, "revocation" was used to describe the "right" of a party to elect possible liability for breach rather than carry out his "obligation" to arbitrate. ${ }^{18}$ This history, however, does not clarify the meaning of the term as used in the statutes, for by making such contracts enforceable, if valid, the legislatures have taken away the right of election to which the term originally related. "Revocation" is usually employed in contract law with respect to the withdrawal of an offer, ${ }^{19}$ and it seems to have no other technical or clearly defined meaning. If the word is used as an equivalent to "rescission," a term more appropriate to an existing contract, technical questions are presented by the vagueness of the concepts of "void" and "voidable" and the uncertainty as to grounds for rescinding the arbitration clause as distinguished from the other, substantial, provisions. But if meaning is to be given to the term it seems nonetheless necessary to rely on the analogy; and such reasoning does not support the implication of the $R F C$ case. For, in any case, it appears that grounds for cancellation of any contract by a party are much narrower than the range of legal or equitable bases for a court's denial of enforcement of it. For instance, the running of the statute of limitations, waiver, hardship or laches-as in the $R F C$ case-do not make a contract invalid, but simply bar a particular remedy. On the other hand, nonage or other incapacity, or fraud in the making might be grounds for rescission by a party. Thus the latter, but not the former, are defenses which a court may entertain in determining whether to enforce arbitration. Only this interpretation of "revocation"

${ }^{15} 204$ F. $2 d 366$ (C.A. 2d, 1953).

${ }^{16} 126$ F. 2d 978 (C.A. 2d, 1942).

${ }^{17} 204$ F. 2d 366, 369 n. 10 (C.A. 2d, 1953).

${ }^{18}$ Sturges, Commercial Arbitration and Awards $\$ \$ 15,76$ (1930).

191 Williston, Contracts $\S 55$ (Williston \& Thompson rev. ed., 1938). 
is consistent with the mandatory language of Section 4-that a compelling order should issue on a finding of valid "making of the agreement" alone. ${ }^{20}$

Secondly, if Section 2 were the source of equitable discretion as the RFC case would indicate, it may be that only a particular class of contracts among many covered by the Act would be subject to such discretion. While Section 2 refers to contracts arising out of interstate commerce and enumerated maritime transactions, Sections 3 and 4 provide that the appropriate remedies may be invoked whenever a federal court would, save for the arbitration agreement, have jurisdiction over the dispute. At present, the circuits are in conflict as to whether Section 2 confines the entire Act to the enumerated transactions. ${ }^{21}$ The Second Circuit has had no real occasion to decide this question though in occasional dicta it has indicated that Section 3 and perhaps Section 4 are broader in scope than Section 2 and may not be limited to interstate commerce and maritime transactions..$^{22}$ If this view is correct, Section 2 contracts will be treated differently from those falling only under Sections 3 and 4, for Section 2 appears to be a source of equitable discretion only as to transactions falling within its limits. In other words, contracts involving interstate and maritime transactions would be subject to equity, while other contracts over which the federal courts have jurisdiction would not. There is no reason to suppose that such different treatment was contemplated. Thus whether Section 2 can reasonably be considered a source of equitable discretion would appear to depend in part upon whether its coverage, and that of Sections 3 and 4, are in fact coextensive.

${ }^{20}$ The New York courts, without defining "revocation," have occasionally suggested that all issues subsequent to the making of a valid agreement are reserved to arbitration. Matter of Lipman (Haeuser Shellac Co.), 289 N.Y. 76, 43 N.E. 2d 817 (1942). Consult: Judicial Innovations in the New York Arbitration Law, 21 Univ. Chi. L. Rev. 148 (1953). But cf. In re Kramer \& Uchitelle, 288 N.Y. 467, 43 N.E. 2d 493 (1942). Occasional attempts to define the term have given it a meaning substantially the same as rescission or cancellation. Zimmerman v. Cohen, 236 N.X. 15, 139 N.E. 164 (1923); Manufacturers Chemical Co. v. Caswell Strauss \& Co., 259 App. Div. 321, 19 N.Y. Supp. $2 d 171$ (1st Dep't, 1940).

${ }^{21}$ In the Third Circuit, substantial precedent was recently overruled and the entire Act was held to be confined to interstate commerce and maritime transactions as defined in Section 1. Amalgamated Ass'n of Street Employees v. Pennsylvania Greyhound Lines, 192 F. 2d 310 (C.A. 3d, 1951). See also, Tejas Development Co. v. McGough Bros., 165 F. 2 d 276 (C.A. 5th, 1947). The Fourth Circuit still holds that the Act is not so confined and other courts appear to take a similar view. International Union United Furniture Workersv. Colonial Hardwood Flooring Co., 168 F. 2d 33 (C.A. 4th, 1948); Agostini Bros. Bldg. Corp. v. United States, 142 F. 2d 854 (C.A. 4th, 1944); Wilson \& Co. v. Fremont Cake \& Meal Co., 77 F. Supp. 364 (D. Neb., 1948), aff'd 183 F. 2d 57 (C.A. 8th, 1950); Pioneer Trust \& Sav. Bank v. Screw Machine Products Co., 73 F. Supp. 578 (E.D. Wis. 1947). For a full discussion of this conflict, see Sturges and Murphy, Arbitration under the United States Arbitration Act, 17 Law \& Contemp. Prob. 580 (1952).

22 Other circuits have relied upon language in Shanferoke Coal and Supply Corp. v. Westchester Service Corp.; 70 F. 2d 297 (C.A. 2d, 1934), and Krauss Bros. Lumber Co. v. Bossert \& Sons, 62 F. 2d 1004 (C.A. 2d, 1933), to the effect that Section 3, at least, is broader in scope than Section 2. Cf. In re Pah lberg Petition, 131 F. 2d 968 (C.A. 2d, 1942); San Carlo Opera Co. v. Conley, 72 F. Supp. 825 (S.D. N.Y., 1946). But see Lewittes \& Sons v. United Furniture Workers, CIO, 95 F. Supp. 851 (S.D. N.Y., 1951). 
A second possible ground for the use of equity power can perhaps be derived from Judge Frank's remarks in Kulukundis Shipping Co. v. Amtorg Trading Corp.: $:^{23}$

It may well be that in a proceeding under Section 4, there are open many of the usual defenses available in a suit for specific performance. . . . However that may be, the same equitable considerations should surely not be applicable when a deferdant asks a stay pursuant to Section 3. For he is not then seeking specific performance (i.e., an order requiring that the parties proceed to arbitration) but merely a stay order of a kind long familiar in common law, equity and admiralty actions. ... There is a well recognized distinction between such a stay and specific performance: The first merely arrests further action by the court itself ... until something outside the suit has occurred.... The second, through the exercise of discretionary equity powers, affirmatively orders that someone do (or refrain from doing) some act outside the suit.24

This reasoning seems inconsistent with the suggestion in the $R F C$ case that the source of equity power is the language of Section 2, for if the latter were the case it would seem anomalous that the discretion could be exercised only with respect to the compelling order and not the stay. But in the Kulukundis case the emphasis is not on the particular language of Section 2 but on the inherent and traditional nature of the court orders as the source of equity powers. The court, seeming to assume that Congress did not intend to create any new form of remedy in the Act, indicates that the statutory remedies are to be invoked according to the principles which govern their common-law counterparts. Under this assumption, it is difficult to explain why Congress spelled out in detail the available remedies and methods of applying them. Moreover, it seems likely that the remedies would have been given their traditional labels-at least as to the order compelling arbitration. But aside from these objections, it will be shown that other difficulties confront any attempt to characterize Sections 3 and 4 in the manner suggested by the court.

The court asserts that the Section 3 remedy is "merely a stay order of a kind long familiar in common law, equity and admiralty actions." Nevertheless, it indicates that discretionary equity power should not be exercised in granting the stay. Since the order is familiar in both equity and law, it is difficult to see why the stay must be granted strictly according to law while the compelling order is subject to equitable discretion. Whichever remedy is invoked, the fundamental purpose of the Act is to force a recalcitrant party to proceed to arbitration. Making the exercise of discretion depend solely upon which remedy happens to be necessary in the particular case seems unreasonable. Moreover, for purposes of determining whether an appeal may be taken from the issuance or denial of a stay order, the courts have uniformly deemed the order an inter-

${ }^{23} 126$ F. 2d 978 (C.A. 2d, 1942).

${ }^{24}$ Ibid., at 987. 
locutory injunction, "an equitable defense or cróssbill interposed in an action at law." 25

The Section 4 order compelling arbitration has been almost universally characterized as a decree of specific performance, without adequate analysis of the difficulties presented. Thus, the court in the Kulukundis case apparently reasoned that because the order requires the defendant to act affirmatively, or at least to refrain from doing some act outside the suit, some flexibility and discretion to meet the peculiarities of each case must be allowed. Judge Frank cited the Supreme Court decision in Hecht Co. v. Bowoles ${ }^{26}$ to the effect that Congress could not intend, without the most explicit language, that the courts should grant specific performance stripped of the equitable considerations which traditionally control its application, and concluded that equitable discretion must be permitted under Section 4.

Professor Sydney P. Simpson has suggested that the compelling order could be classified as specific enforcement only if failure to comply could be punished by the usual equity sanctions, i.e., contempt proceedings, sequestration and imprisonment. ${ }^{27}$ He reasoned that perhaps the legislators intended the courts to restrict themselves in case of such non-compliance to the measures provided in the statute-appointment of arbitrators with power to summon witnesses and entry of judgment upon the award. In this interpretation the Act's remedy in Section 4 would be characterized not as specific enforcement in the traditional equity sense but as a new statutory form of relief. As such, it would be subject to no controlling principle of common law or equity which could arguably override the mandatory statutory language. Thus the compelling order would issue automatically upon a finding of the making of an agreement and neglect or refusal to perform. To the objection that Simpson's analysis limits the effectiveness of the compelling order to the threat of judgment on an award by courtappointed arbitrators-the only statutory sanction for non-compliance-it may be noted that the order serves at least as a preliminary inducement for the parties to cooperate in proceeding to arbitration.

Another indication that a compelling order is improperly characterized as a specific enforcement decree is provided by one of the cardinal principles of equity-that equitable remedies are available only if the legal remedies would be inadequate. If a court could not settle the merits of the dispute before it as quickly and effectively as an arbitration board, it might be said that this is the case. But such a conjectural determination could hardly provide a sound basis for controlling the use of equitable discretion in issuing the compelling order. On the other hand, if a court sits in equity and grants equitable remedies when

${ }^{25}$ Shanferoke Coal and Supply Co. v. Westchester Service Co., 293 U.S. 449, 452 (1935); Gatliff Coal Co. v. Cox, 142 F. 2d 876 (C.A. 6th, 1944).

${ }^{28} 321$ U.S. 321 (1944).

${ }^{27}$ Simpson, Specific Enforcement of Arbitration Contracts, 83 U. of Pa. L. Rev. 160, 170-71 (1934). 
applying the Arbitration Act, then the legal remedies are clearly inadequate since a court of law would have to apply the common law which gave only nominal damages for breach. Perhaps such confusion has induced the courts to avoid discussing the issue at all.28

It is also significant in characterizing the compelling order that specific enforcement ordinarily requires an affirmative act on the part of the person to whom the order is directed. The order seems not to have such effect for the defendant is not required to appear and argue his side of the case. He canstand mute and suffer award and judgment by default. In this respect the order has the same effect as the basic legal requirement that all complaints be answered regardless of their merits and that judgment be rendered summarily in case of default. And of course the legal system allows the courts no discretion in this regard.

Finally, it is important to note that while specific enforcement involves either a temporary or final determination of substantive rights, the order compelling arbitration affects only the procedure by which those rights are determined. The order does not enforce the contract but rather shifts the trial of a dispute to another tribunal on the basis of prior consent to the arbitrator's jurisdiction. ${ }^{29}$ For the courts to assume that such a shift will as a practical matter prejudice the substantive rights of the parties is an assertion of the very distrust in the arbitration process which Congress intended to eliminate. When a court is required to decide its own or another tribunal's jurisdiction, it may in some cases exercise a degree of discretion-witness the doctrine of forum non conveniens. But such discretion is not an inherent and necessary power of the court as in the case of specific enforcement; a statute may set the bounds of court jurisdiction and leave no room for discretion. This is what the Arbitration Act appears to do, requiring that upon certain conditions all disputes shall be referred to arbitration.

Only if the compelling order is properly characterized as specific performance. is the rationale of $B$ echt Co. v. Bowles ${ }^{30}$ relevant. There, an injunction had been issued under the Emergency Price Control Act to prevent violation of maximum

${ }^{28}$ Commentators have expressed only passing recognition of the problem and have not agreed in their conclusions. Consult Phillips, The Paradox of Arbitration Law, 46 Harv. L. Rev. 1258 (1933); Simpson, op. cit. supra note 27, at 161. Compare Pomeroy, Specific Performance of Contracts $\$ \$ 47-50$ (1941).

${ }^{29} \mathrm{~A}$ rough comparison can be made between arbitration contracts and other contractual consents to jurisdiction. For example, where the maker of a cognovit note has contracted in advance for confession of judgment without personal service, the court, in assuming jurisdiction, is not specifically enforcing that obligation but rather is concerning itself with a simple prior consent to the jurisdiction.

It will be noted that this comment adopts the prevalent view that arbitration is merely a substituted mode of trial. No attempt will be made here to defend this view in opposition to the so-called agency-contract theory of arbitration. For the classic exposition of these two theories, consult Isaacs, Two Views of Commercial Arbitration, 40 Harv. L. Rev. 929 (1927).

20321 U.S. 321 (1944). 
price regulations. The Court announced the principle that a statute establishing remedies equitable in nature should not be construed to withdraw equitable discretion without explicit language to that effect. However, in that case, the use of discretion was perhaps justified because substantive rights were being finally determined. As to the compelling order, it has been shown, this is not the case. Thus neither the analysis of the Kulukundis case nor the authority of Hecht Co. v. Bowles seems persuasive that equitable discretion is properly available to courts under the arbitration acts.

\section{III}

Apart from the interpretation placed upon the acts by the courts in this regard, the question remains whether equitable discretion in its application is desirable..$^{31}$ It is clear that by invoking equity powers the courts have significantly narrowed the area in which arbitration operates. And alighting upon the words "equity" and "revocation" in Section 2 the courts have in some cases exercised discretion to decide substantive issues in dispute. For example, assume that a contract is made and upon substantial breach one party cancels. The court, instead of summarily ordering arbitration, proceeds to determine whether the contract exists; this may depend upon the nature and justification for the breach and subsequent cancellation-the very issues the parties had agreed to arbitrate.

As a result of identifying the Section 4 order as specific enforcement the courts have exercised an even broader discretion, recognizing many defenses which go to the merits of a dispute under a contract whose validity is not in dispute. Discretion in compelling arbitration invites a judgment by the court as to whether the issue in dispute can best be handled by the arbitration process. And if some phase of the controversy involves complex legal matters, or if for any reason the court feels that arbitration is not appropriate, the entire dispute may be withheld from the arbitrators; again the court's jurisdiction is expanded and that of arbitration is contracted.

The practice of the courts in deciding issues which arbitration could competently handle is perhaps understandable in view of Section 10 of the federal act, and the equivalent provisions in others, which purport to eliminate judicial review of errors of law in the arbitrators' decision. This section of the Arbitration Act allows a court to make an order vacating the arbitrator's award upon certain enumerated grounds. These include (1) procur.ment of the award "by corruption, fraud or undue means," (2) "evident partiality or corruption in the

s1 Judge Frank in Kulukundis Shipping Co. v. Amtorg Trading Corp., 126 F. 2d 978 (C.A. 2d, 1942), suggested that if equitable discretion were not available, litigation-which the arbitration acts are designed to reduce-would be augmented. But if either party to an arbitration contract may resort to the courts for relief from his obligation whenever it seems inequitable to perform, it is difficult to conceive how litigation will be reduced. Strict judicial enforcement would leave the parties with nothing to litigate except the merits and that would have to be done through arbitration. 
arbitrators," and (3) "any other misbehavior by which the rights of any party have been prejudiced." No explicit mention is made of a power to vacate an award on the grounds that the arbitrator misinterpreted or misapplied the law. While a majority of the Supreme Court in Wilko v. Swan $n^{32}$ indicated that the statute precludes judical review of errors of law, one Justice preferred to reserve decision on this matter and two asserted that such review was allowable. The critical feature of that decision is that all of the Justices felt that this question had some bearing on whether or not to send the particular dispute to arbitration. Since judges seem unwilling to allow such errors to go uncorrected or to relinquish their jurisdiction over the legal issues in dispute, this aspect of the decision may strengthen their inclination to exercise their influence when they canin deciding whether a stay or compelling order will issue.

Congressional policy favors arbitration in both commercial and labor disputes. ${ }^{33}$ Of course, in certain areas of dispute this policy may be overridden. For example, the Supreme Court in the Wilko case felt that the protection afforded to investors under the Securities $\mathrm{Act}^{34}$ could not be effectively guaranteed by the arbitration process. But in the case of the ordinary commercial dispute the policy favoring arbitration ought to prevail.

If the courts, denied the power of review, may still prevent arbitration of the dispute, the dominant policy of the Act is frustrated. To withhold a dispute from arbitration means that even issues of fact are tried by the courts. To review an award means that the arbitrator's findings of fact are conclusive; only his application of the law is subject to scrutiny. If this power of review were available to the courts, as it is in England, ${ }^{35}$ both the arbitrators and the courts might operate in the area where they are most effective.

The division of jurisdiction between the courts and arbitration need not, necessarily, be based solely on the distinction between issues of law and fact. Empirical investigations of arbitration now in progress may show that the process does not function well, from the viewpoint either of the parties or of a commercial society, in certain areas. ${ }^{36}$ If this is true, Congress might well prescribe that certain disputes are to be settled with the aid of the judicial machinery. But it seems unwise to allow the courts discretion in deciding when the

\footnotetext{
22346 U.S. 427 (1953), rev'g 201 F. 2d 439 (C.A. 2d, 1953), rev'g 107 F. Supp. 75 (S.D.N.Y., 1952).
}

${ }^{23}$ " $[1] \mathrm{t}$ is the policy of the United States that ... (b) the settlement of issues between employers and employees through collective bargaining may be advanced by making available full and adequate governmental facilities for conciliation, mediation and voluntary arbitration. ..." Taft-Hartley Act \$ 201, 61 Stat. 152 (1947), 29 U.S.C.A. \$ 171 (Supp., 1953).

34 Securities Act of 1933, 48 Stat. 74 (1933), 15 U.S.C.A. $\$ \S 77$ a et seq. (1952).

${ }^{25}$ The Arbitration Acts (Eng.), 52 \& 53 Vict. c. 49 (1889), 24 \& 25 Geo. V, c. 14 (1934).

${ }^{36}$ For discussion of a research project on this and related problems now under way at the University of Chicago Law School, consult Mentschikoff, The Significance of Arbitration-A Preliminary Inquiry, 17 Law \& Contemp. Prob. 698 (1952). 
judicial process is to give this aid. ${ }^{37}$ For the courts, in their case-by-case encounters with arbitration, are necessarily concerned with particular disputes, and not with the broader problem of nurturing arbitration in those fields where it is most competent.

\section{CARRIER'S DUTY OF NOTIFICATION ON AN ORDER-NOTIFY BILL OF LADING}

The problem of a carrier's liability for failure to inform the shipper of goods on an order-notify bill of lading ${ }^{1}$ of a failure of the notify party to accept the goods has recently received renewed attention from the courts. The Massachusetts Supreme Court has considered the problem in Lapp Insulator Co. v. Boston $\& M . R . R .{ }^{2}$ which was a suit by a shipper on an order-notify bill of lading against the carrier for loss by fire of the goods while stored in the carrier's warehouse. The goods had arrived at their destination and the notify party had been duly informed, but it had not accepted them at the time of their destruction. The notify party had repeatedly promised the carrier that it would accept the goods and pay storage charges, if the latter would hold them. The carrier failed to notify the shipper of the goods of the non-acceptance, however, and on this basis the court held the carrier liable to the shipper for the value of the goods.

The only other case which has arisen concerning this problem since $1934^{3}$ is Tri-State Produce Co. v. Chicago, B. \& Q. R. Co., ${ }^{4}$ decided in the Federal courts in $1952 .{ }^{5}$ There a duty of notification was imposed on the carrier under similar circumstances. ${ }^{6}$ While the Lapp Insulator result is in accord with that reached

${ }^{37}$ Law review discussions treating the cases in detail have analyzed the problem of jurisdiction of court and arbitrator from other viewpoints without specific consideration of the role of equity. Judicial Innovations in the New York Arbitration Law, 21 Univ. Chi. L. Rev. 148 (1953); Judicial Control of Arbitrators' Jurisdiction in New York, 38 Cornell L.Q. 391 (1953); Arbitration: Its Snares and Delusions, 19 Brooklyn L.-Rev. 199 (1953).

${ }^{1}$ In this type of bill the shipper is both the consignor and the consignee of the goods. There is a direction to the carrier to notify a party at the destination point. Typically this party (the notify party) is the buyer of the goods, and upon presentation of the bill of lading.to the carrier is entitled to possession. The practice is for the seller to tender the bill of lading together with a sight draft through banking channels; upon acceptance of the draft the bank releases the bill of lading to the buyer, who then obtains the goods from the carrier.

2- Mass. -, 112 N.E. 2 d 359 (1953).

${ }^{3}$ In that year the Third Circuit Court of Appeals passed on the problem in Trinidad Bean \& Elevator Co. v. Pennsylvania R. Co., 72 F. 2d 371 (C.A. 3d, 1934).

104 F. Supp. 452 (N.D. Iowa, 1952), noted in 66 Harv. L. Rev. 351 (1952), and 37 Minn. L. Rev. 204 (1953).

5 Possibly the dearth of decisions during the period 1935-1952 is reflective of the general economic situation then prevailing. It will be noted that in a period of growing demand for goods it is less likely that buyers will fail to accept goods shipped to them; thus the situation requiring notice by the carrier to the shipper less frequently arises.

- There was no actual recovery in the Tri-State case even though the court found liability for the failure of the carrier to notify, since no loss was proved by the evidence. (The goods involved were frozen turkeys, and damages were alleged to have accrued from a drop in the 